\title{
How and Why to Implement HACCP in Food Businesses in Developing Countries? Suggestions to Afghan Government and Private Sector
}

\section{Sayed Mohammad Naim Khalid*}

Independent Food Safety and Quality Consultant, Company Area, $5^{\text {th }}$ district, Kabul, Afghanistan

\begin{tabular}{l} 
A R T I C L E I N F O \\
Article history: \\
Received 13 February 2015 \\
Accepted 24 March 2015 \\
Available online, ISSN: 2148-127X \\
\hline
\end{tabular}

Keywords:

Food business

HACCP

Food safety

Public health

Afghanistan
A B S T R A C T

In Afghanistan food safety is managed by several ministries including Ministry of Public Health, Ministry of Agriculture, Ministry of Commerce and municipalities. There is no food law but multiple ministerial decrees which ensure if GMP is implemented well. There is no legal requirement to get food safety certification. Hazard analysis and critical control point (HACCP) is recognized as a key part of food safety management practice in the global food industry and can be applied at any stage of the food supply chain. This article discusses accepted approaches to the application of HACCP principles for the development, implementation, and maintenance of HACCP plan. It is intended as an introduction to food safety system in Afghanistan, giving propositions to government on how to apply the principles in a stepwise approach, and showing how HACCP benefit public and private sector and also suggesting ways how to adapt this approach in the food businesses.

\footnotetext{
${ }^{*}$ Corresponding Author:

E-mail: sayednaim@outlook.com
}

\section{Introduction}

The food industry in most countries is a major sector, sometimes accounting for the highest proportion of the gross domestic product (GDP). The food industry comprises mainly small businesses which are responsible for a large share of the food consumed. Food businesses also provide a large share of the total employment in the employment sector and make a vital contribution to the economic well-being of the community at local level. The national government aim for businesses to thrive including the food business, but they must at the same time protect public health. To this end, it is important to develop a food safety policy and strategy for the implementation of HACCP because most of food borne diseases are due to poor handling practices (Adesokan et al., 2015). While not food exporters, food businesses have a strong impact on local and regional economies and a potentially immense impact on the health of local consumers and therefore national public health. The food businesses in all level including small, medium and large can implement HACCP. In 2001, the concept of defining small businesses on the basis of their qualities was introduced (Taylor, 2001):

- They serve local customers.

- They have a limited share of the available market.

- They are owned by one person or by a small group of people.

- They are mostly owner-managed and independent of ownership by larger groups of companies.
Government is responsible for public health $\mathrm{MoPH}$, 2009) and economic development; improvements in food safety including the implementation of HACCP in food businesses can have a positive effect in both areas. Agriculture and the agribusiness sector make an important contribution to the national economy of Afghanistan (Rahimi, 2014). A wide range of stakeholders should work towards the common goal of food quality and safety. The stakeholders include government departments (health, agriculture (Wong, 2007), education, development, trade and industry/enterprise), scientific institutes, food associations, trainers, advisors and auditors. It also has external influences like buyers, accreditation organizations and standard-setting agencies (FAO, 2007; Wu, 2013). The public and private partnership and coordination are necessary to be in place for achieving good results (Klaeijsen, 2013; Herath and Henson, 2005). The use of Hazard Analysis and Critical Control Point (HACCP) based quality assurance has a well-established place in controlling safety hazards in food supply chains. It is an assurance system based on the prevention of food safety problems and is accepted by international authorities as the most effective means of controlling food-borne diseases (Stanley et al., 2011).

In Afghanistan, the food safety culture is poor. Nowadays media are mainly focused on "well eating" but final consumer has no real strategy to fight hazards due to food pathogens (Cecaro, 2014). Death and hospitalization 
consequent to food poisoning infections are frequent and represent a serious threat for all countries. A possible solution could be give more responsibility to the final consumer, using clear labels (Khalid, 2015) which highlight products' safety, similar to the Critical Control Point (CCP) which are part of HACCP. This is extremely important for young, old, pregnant women and immune deficient people (YOPI) which are very sensitive to small contaminations from bacteria (Khalid, 2012b). This measure could actually reduce food poisoning, foodborne disease and in turns decrease costs of health care (FAO, 2007; Anandappa, 2013). The purpose of this article is to explore how HACCP and why HACCP is implemented in other countries and propose solutions to Afghan government to use this approach in the food businesses to reduce the burden of food borne disease and get customer satisfaction.

\section{Overview of Food Sector in Afghanistan}

According to a report of British Broad Casting (BBC), municipalities are responsible for ensuring hygiene at bakeries (Khelwatgar, 2009). Bakeries bring wheat flour and keep it in the same place with no proper storage practices. There are no standard hygiene practices, hand washing facility is not available, air ventilation, ceiling, floor and walls are not according to the Codex requirements. The same is the situation of butchers' shop. There is no pest control system in place. Cleaning of equipment, structure of floor, ceiling, walls and entry is not according to basic requirement set by Codex standards (Khalid, 2012; Khalid, 2014). In retail and whole sale level almost every kind of food items perishable and Nonperishable are found in the premise. The country imports most of the cereal crops including wheat, rice and corn. Edible oil is also imported from other countries (FICCI and ESCAP, 2013). There are small number of Small and Medium Enterprises which includes wheat milling, cooking oil packaging, fruit processing, vegetable processing (Shah, 2009), biscuit production, meat storages/distribution and a huge number of bakeries. The food retail shops and butcher shops need urgent attention from policy makers. The processing activities are mainly conducted in industrial parks like in Herat, Mazar, Kabul, Kandahar and Nangrahar provinces (AISA, 2013). In butcher shops there are some illegal activities like selling of dog meat with fake label as mutton (Sabir, 2014). The same is the case of street foods. The restaurants and hotels are controlled by MoPH and Municipalities. Hygiene and safety requirement including hand washing, pest control, safe storage practices, waste control and cleaning plans are not in place (Gulkohi, 2010; Eslah Newspaper, 2014). Different legal documents are available but are not enforced due to poor capacity, lack of political will and fragmented control system and lack of clear understanding of farm to table food safety approach (Ayra, 2005; Zafar, 2005).

\section{National Food Safety System in Afghanistan}

Food safety is managed in absence of food safety law but there are the Veterinary Law and the Public Health
Law which are touching the issue of food safety indirectly (Khalid, 2014; MoPH, 2011; Hamid, 2015; Quraishi, 2012; NMFB, 2014). A brief list of the system management is presented as below:

- Oversight responsibilities lies with Ministry of Agriculture, Irrigation and Livestock (MAIL) (raw food) and Ministry of Public Health (MoPH) (processed food),

- National Medicine and Food Board with Food Committee policy advisory role,

- Raw animal products are inspected by Animal Health Directorate of MAIL,

- Raw plant products are inspected by Plant Protection Directorate of MAIL,

- Processed food is inspected and controlled by Quality Control Directorate of MoPH,

- Good Manufacturing Practices (GMP) compliance checked by Environmental Health Directorate and Health Law Enforcement Directorate of MoPH and Municipality,

- Fortified foods regulatory affairs managed by Public Nutrition Department of MoPH,

- Markets are controlled by MAIL, MoPH, Ministry of Commerce and Municipalities,

- Food Standards are developed by Afghanistan National Standard Authority (ANSA). There are 34 approved standards for some food commodities,

- Advisors from outside play significant role in food safety issues,

- There is no enacted food law but a public health law with focus on preventive health,

- There are more than 15 Ministerial Decrees (Layha) on GMP and Good Hygiene Practice (GHP) in the food services and processing sector,

- No mandatory food traceability,

- Random inspection of imports which is free,

- Importer pay for the quality/safety tests of further inspection.

\section{What is HACCP?}

Hazard analysis critical control point (HACCP) is a risk management (Gilling, et al., 2001), science based system (Featherstone, 2015) developed to control food safety. It can be described as an operation-specific, internally managed system of preventative control that identifies, evaluates, and controls hazards of significance to food safety (Goodrich-Schneider et al., 2012). While it has a relatively long history, originating as a mean of assuring the safety of meals produced for the first U.S. manned space program in the 1960s, it is only in the last 10 years that it has emerged as the primary approach to securing the safety of the food supply globally (Wallace, 2014). This is reflected in recommendation of HACCP by organizations such as the International Commission on Microbiological Specifications for Foods, and a Codex Alimentarius Commission (Codex Alimentarius, 1993) decision to recommend its use by both the food industry and regulatory authorities. This latter development has had a direct effect on the countries of the European Union 
who have since built a requirement for risk management, based on HACCP principles, into the operational activities of all food businesses (Gilling et al., 2001).

The HACCP approach can be used in bakeries (Trafialek and Kolanowski, 2014), dairies (Cusato et al., 2013; FDA, 2007), cooking oil, hotels, restaurants (Wu, 2013; Khalid, 2012b), meat industry (Boland et al., 2001; Maldonado-Siman, et al., 2014), food storages, supermarkets, juice companies, chocolate company, ice cream company (Lu et al., 2014), catering services (Garayao et al., 2014) and agriculture products processing companies (Anandappa, 2013).

\section{The Food Safety Burden}

Afghanistan is a country with a draft food law which is still not enacted (Khalid, 2015). There are no clear data on the food borne disease. Globally, data from WHO suggest that food-borne disease (together with water) is a significant contributor to mortality from diarrheal disease as a result of which 2.2 million deaths occur annually (FSA-UK, 2011). Each year, foodborne disease causes an estimated 48 million illnesses, 325.000 hospitalizations and 3.000 deaths in the United States of America (CDC, 2013), and 1 million cases, 20.000 hospitalizations and 500 deaths in England and Wales and it costs us nearly $£ 1.5$ billion (FSA-UK, 2011). A recent OECD (Organization for Economic Co-operation and Development) report assumed that the burden of foodborne disease is probably similar in most OECD countries. Many countries, including developing countries, lack strong surveillance and reporting systems and therefore statistical estimates are not available. Furthermore, food-borne disease often goes unreported, with the result that the economic and health impacts are greater than the figures suggest in many countries. Improvements in the protection of public health rely on improvements in the safety of food. In this regard, governments, the food industry and consumers have a shared responsibility to adopt the best practices for the control of food safety hazards (FAO, 2007).

What are the problems that food business faces in terms of implementing HACCP?

Food business face many challenges while developing and implementing HACCP plans in their facilities. The literature present different kinds of problems that hinder either government or private sector to successfully implement HACCP (Cusato et al., 2013; Stier et al., 2003; SÖZEN and HECER, 2013; Mortimore, 2001; Rostron, 2012; Gilling et al., 2001; Miljkovic et al., 2009). Some key problems are as below:

- Infrastructure and facilities: HACCP means additional costs in upgrading facilities before the system is even applied,

- Basic hygiene: Good hygienic practices tend to be lacking. The problems include inadequate location, layout or size of facility, non-cleanable structures, old non-cleanable equipment and poor staff training, easy access to potable water, safe disposal of waste, difficulty to obtain raw materials from reliable and affordable sources,
- Awareness and expertise: in Afghanistan the government authorities just know the name of HACCP not the way how it is implemented and its importance,

- Education and training: For successful HACCP implementation, the concept must be understood by food business owners and managers,

- Lack of technical support: Food businesses often lack the technical expertise required to implement HACCP and may need external support,

- A shortage of appropriate and accurate advice and guidance for businesses from government side,

- Human resources: In Afghanistan there is no restaurants education and even food safety is not incorporated in the faculties lecture,

- Financial issues: The annual income of an Afghan is around \$ 665 (World Bank, 2015) to \$ 1100 (Mundi Index, 2014), therefore, financial constraints are a practical barrier to implementing HACCP. A study on the costs of the development and implementation of HACCP, SSOP's, Salmonella Performance Standards, and Generic E. coli Process Control Testing for small meat and poultry plants found out that it costs $\$ 0.009$ per pound in some of the USA states (Boland et al., 2001),

- Government infrastructure and commitment: government and its associated agencies and bodies must be committed to HACCP systems. External and internal commitment is important for the development and implementation of a successful HACCP initiative. An appropriate common policy for the application of GHP/HACCP in food businesses is needed to achieve uniformity among trainers. Insufficient government commitment (Wu, 2013), inadequate professional knowledge of HACCP (including inadequately trained auditors), poor coordination within government structures and/or inconsistency in HACCP enforcement or application are not conducive to the creation of a food safety culture in which HACCP can thrive,

- Legal requirements: Food businesses can be persuaded to implement HACCP when it is a legal requirement and importantly properly enforced. The presence alone of a legal requirement is not sufficient to stir all food business owners into affirmative action, but it can be considered part of a framework to promote HACCP implementation. The HACCP system can be made voluntary (FDA, 2007) or mandatory by government (GoodrichSchneider et al., 2012; Motarjemi et al., 2014),

- Low levels of literacy and use of multiple languages amongst those working in the food industry,

- Communication: Poor communication between governments, industry and consumers impede the introduction of HACCP. Communication strategies-covering the content of the communication as well as the channels for communication-need to be part of any HACCP 
policy or strategy. Often the only point of official contact with food business is through official inspectors; if these people are not resourced, trained and allowed to provide advice as well as conduct official inspections, it can hamper a national strategy aimed at increasing HACCP implementation.

- Poor food safety culture. Now a-days media are mainly focused on "well eating" but final consumer has no real strategy to fight hazards due to food pathogens. Media could educate on food safety culture, especially categories of high risk subjects (Cecaro, 2014). But quality of food is considered more and more by consumers (CIRAD, 2013).

\section{Role of Government and Potential Benefits}

The role of Afghan government goes beyond adopting and monitoring compliance with national food legislation: the government should actively promote food safety measures through the adoption of food safety management systems such as HACCP. The success with which food businesses establish and implement HACCP may be directly related to the supporting environment created by the government, including alliances with food businesses. Food businesses face very significant challenges when adopting HACCP, and active intervention by the government is required. In Afghanistan, the food business sector accounts for a substantial part of the economic industry, makes an important contribution to the national food supply and is an important source of employment contributing to the local economy. It is therefore important that a national policy is adopted to increase levels of food safety in this sector. At the same time, advocacy of the HACCP system provides mutual benefits to the government, including safer food and hence increased public health protection, which in turn may increase the confidence of both national consumers and exports. This, combined with better opportunities to increase trade, results in economic growth and national development.

\section{What is The Role of Private Sector?}

Food businesses bear the ultimate responsibility for assuring the quality and safety of the foods they produce (Khalid, 2012b; Massimo et al., 2013). The food must reach the consumer in its intended state and there must be adequate consumer information concerning the intended use of the product. Food businesses are under growing pressure from governments and buyers to demonstrate that they implement effective systems to meet basic GHP and HACCP requirements for food safety. Initial responsibility for HACCP lies within the food industry, in particular with management:

- Food must be produced in a hygienic manner.

- The source of incoming raw materials must be considered.

- A risk-based approach -such as the HACCP system- must be implemented to achieve food safety.
Food businesses are also required to interact and comply with government requirements regarding food safety management systems, inspection and auditing. Food industry associations give food businesses a stronger voice in discussions with government and other interested parties, and help work towards improving the overall standard of a specific food sector. They can also raise awareness, promote technical transfer of information and increase provision of training.

It is recognized worldwide that the HACCP system:

- provides clear benefits to food businesses,

- enhances the safety of food; and

- reduces cases of food-borne disease.

Benefits resulting from the implementation of HACCP systems have been identified (Fsai, 2009; Taylor, 2001; CFS, 2007; IFC, 2011; Maldonado et al., 2005) and some are described below:

- Staff and business owners gain confidence and are better equipped for informed discussion on food safety measures with food inspectors, third party auditors, consultants, trading partners, consumers and others,

- A HACCP system is essentially a management tool and its development requires an investment resulting in cost reductions to small food business in the medium and long term: more efficient use of staff, provision of adequate documentation and reduced waste,

- The increased level of process control can result in product consistency and improvements in traceability, with beneficial cost implications for food businesses as access to some markets is increased and more customers are attracted,

- The development of a HACCP system can be a valuable team-building exercise for a food business; it can lead to improved education and awareness of staff working in food businesses and staff members are empowered when their input is sought and valued; this in turn can have a positive effect on the development of the food businesses, as it demonstrates an ability to manage change,

- HACCP provides a basis for defence against litigation and can bring reduced insurance costs,

- Better shine corporate image of the business ( $\mathrm{Wu}$, 2013)

\section{How to measure successful implementation of HACCP?}

Indicators help us decide whether HACCP is being successfully implemented; it is then possible to decide whether targets have been achieved and to determine the success. The relevant indicators depend on different circumstances and the strategic approach adopted. Research in this area is still in its infancy but some indicators have been determined (FAO, 2007) and are given below as guidance:

- History or track record of the food business:

○ number of compliance violations;

○ findings of enforcement officers; and

- number of associated food safety incidents, 
- Number of consumer complaints (either by business or by sector),

- Change in number of reported food-borne illnesses associated with a business or sector,

- Number of certified businesses in a sector,

- Number of product recalls in a business or sector,

- Number of rejections or detentions in importing countries,

- Number of new food businesses recorded as having adopted HACCP,

- Results of inspection missions by foreign competent authorities (where relevant). While not strictly quantitative indicators, positive and negative trends can be monitored by reviewing the following:

- Assessment of on-site documentation and records (appropriateness, accuracy and validity),

- Comparison study of business achievements (based on risk management profile, scored inspection report and grading scale),

\section{Recommendations for Government}

This article provides guidance on the application of HACCP in food businesses; nevertheless, a logical approach ensues and it goes without saying that a HACCP system is based upon and should take into account basic prerequisite programs (i.e. GHPs). Prerequisite programs outline the measures taken to ensure that premises, equipment, transport and employees do not contribute to or become food safety hazards. Without these basic principles (e.g. sanitation, pest control, personnel practices), a risk-based system such as HACCP will fail. The application of GHP and HACCP acknowledges two schools of thought:

- All the basic prerequisite programs should be in place in a food business before preparing a HACCP plan,

- A risk-based approach to food safety management can be applied by strengthening the GHP program, while completing the HACCP plan,

- Which path to take (or whether to use a combination of both) is a matter of national policy with due regard to importing country requirements. The basic GHP program is of prime importance for food safety, as stressed in the fourth revision of the Annex on HACCP (contained in the Codex General Principle of Food Hygiene - FAO and WHO, 2003),

- Prerequisite programs to HACCP, including training, should be well established, fully operational and verified in order to facilitate the successful application and implementation of the HACCP system,

- While following these guidelines and considering the national policy options for the application of HACCP in the food business sector, it is necess0ary to take account of the existing food hygiene controls in the food business sector being targeted. What is the existing level of GHPs? Are they adequate? Where is strengthening required?

- Government assessment through planned inspection and auditing programs should review the application of good hygiene principles as well as other food safety management systems operated by the food business. Where GHPs are inadequate, the initial objective of HACCP in food business should be basic hygiene improvement. Hazard analysis can help focus on priority areas where improved hygiene is necessary. A specific HACCP plan -i.e. with identification of CCPs and control charts- could be developed to increase confidence in the control of parameters critical for food safety (WHO, 2014).

\section{Specific Recommendation}

- Government needs to establish various food standards for providing minimum safety standards of food products,

- Legalize food control in country,

- Strengthen the skills of government inspectors to ensure compliance to the set mandates,

- Must provide financial subsidies to the private sector at initial stages,

- Build and maintain adequate food systems and infrastructures (e.g. laboratories) to respond to and manage food safety risks along the entire food chain, including during emergencies,

- Foster multi-sectorial collaboration among public health, animal health, agriculture and other sectors for better communication and joint action.

\section{Conclusion}

HACCP is a useful tool to control hazards in food premises, and in particular in those that proceed to operations that are likely to introduce hazards when not carried out properly. It can be applied throughout the food chain from farm to final consumer. The HACCP allows the principles to be implemented with the required flexibility so as to ensure that it can be applied in all circumstances. Though the initial investment will be high but at long term both private sector and government will gain more. Private sector will increase its sales in domestic and international markets and get fame while government will be able to reduce toll of foodborne illnesses and reduce the public burden of human losses, job losses and finally avoid economic losses. In order to successfully implement HACCP, the government and private sector needs to have rigid commitment and ensure good hygiene and good manufacturing practices prior to starting HACCP.

\section{References}

Adesokan HK, Akinseye VO, Adesokan AG. 2015. Food Safety Training Is Associated with Improved Knowledge and Behaviours among Foodservice Establishments' Workers, International Journal of Food Science, 1: 1-8.

AISA. 2013. Industrial Parks in Afghanistan: Growth, Challenges, and Recommendation, Kabul, Afghanistan: Directorate of Analysis And Evaluation: Afghanistan Invetment Support Agency (AISA). 
Anandappa MA. 2013. Evaluating food safety systems development and implementation by quantifying HACCP training durability ( $\mathrm{PhD}$ dissertation). Lexington, Kentucky : University of Kentucky

Ayra A. 2005. Afghanistan: Market Profile for Emergency Food Security Assessments , Kabul, Afghanistan : World Food Programme, Emergency Needs Assessment Branch (ODAN) .

Boland M, Hoffman DP, Fox J. 2001. Post implementation costs of HACCP and SSOP's in great plains meat plants. Journal of Food Safety 21: 195-204.

CAC/RCP. 2003. Hazard Analysis Critical Control Point (HACCP) system and guideline for its implementation. s.1.:Codex Alimentarious Commission: WHO/FAO.

CDC. 2013. Foodborne Illness and Outbreak Investigations. [Online] Available at: http://www.cdc.gov/foodsafety/ investigations.html [Accessed 31 Jan 2015].

Cecaro M. 2014. Improving food safety culture with a right communication. Journal of Nutrition and Food Sciences, 4: 51

CFS. 2007. Benefits of Implementing a Food Safety Plan. [Online] Available at: http://www.cfs.gov.hk/english/programme/ programme_haccp/programme_haccp_benefits.html [Accessed 1 Feb 2015].

CIRAD. 2013. Food hygiene and veterinary public health in the southern countries: training brucher.

Codex Alimentarius. 1993. Guidelines for the application of the hazard analysis critical control point system. s.1.:WHO/FAO.

Cusato S, Gameiro AH, Sant'Ana AS, Corassin CH, Cruz AG, de Oliveira CAF. 2013. Food Safety Systems in a Small Dairy Factory: Implementation, Major Challenges, and Assessment of Systems' Performances. Foodborne Pathogens and Disease, 10 6-12.

Eslah Newspaper. 2014. Hygiene essentials must be regarded by people. [Online] Available at: http://dailies.gov.af/site /eslah/eslah/specialpage2/health2/4591[Accessed 19 March 2015].

FAO. 2007. FAO/WHO guidance to governments on the application of HACCP in small and less developed food businesses: FAO food and nutrition paper 86, Rome: FAO/WHO.

FDA. 2007. Hazards \& Controls Guide For Dairy Foods HACCP, s.1.: Center for Food Safety and Human Nutrition: Food and Drug Administration of USA.

Featherstone S. 2015. Hazard Analysis and Critical Control Point (HACCP) System in Food Canning. In: A Complete Course in Canning and Related Processes. 4th ed. s.1.:s.n., pp. 215-234.

FICCI and ESCAP. 2013. Doing Business with Afghanistan: Harnessing Afghanistan's Economic Potential, New Delhi, India: Federation of Indian Chambers of Commerce and Industries (FICCI) and UN-ESCAP South and South-West Asia.

Foods (ICMSF). 1988. Micro-organisms in foods 4: application of the hazard analysis critical control point (HACCP) system to ensure microbiologicalsafety and quality. Oxford: Blackwell ScientiŽc.

Fsai. 2009. Benefits of HACCP. [Online] Available at: https://www.fsai.ie/food_businesses/haccp/benefits_of_haccp.ht $\mathrm{ml}$ [Accessed 1 Feb 2015].

FSA-UK. 2011. Food Borne disease strategy 2010-2015: An FSA program for reducation of food borne disease in the UK. 1st ed. s.1.:Food Standard Agency of UK.

Garayoa R, Díez-Leturia M, Bes-Rastrollo M, García-Jalón I, Vitas AI. 2014. Catering services and HACCP: temperature assessment and surface hygiene control before and after audits and a specific training session. Food Control 43:193-198

Gilling SJ, Taylor EA, Kane K, Taylor JZ. 2001. Successful Hazard Analysis Critical Control Point Implementation in the United Kingdom: Understanding the Barriers through the Use of a Behavioral Adherence Model. Journal of Food Protection, 64: 710-715.

Goodrich-Schneider R, Schneider KR, Danyluk MD, Schmidt RH. 2012. HACCP: An Overview: Factsheet. Publication \#FSHN0512 ed. Florida: University of Florida -IFAS Extension.
Gulkohi MR. 2010. Killing street foods (original in Dari). [Online] Available at: http://tkg.af/dari/report/research/3923-ghaza-haimarg-afarin-knar-piada-rawha [Accessed 19 March 2015].

Hamid BA. 2015. Nutrition Status in Afghanistan (translated from Dari). [Online] Available at: http://8am.af/nutritional-status-inafghanistan/[Accessed 6 Feb 2015].

Herath D, Henson S. 2005. Identification and quantification of barriers to HACCP implementation: Evidence from Ontario Food Processing sector. Ontario, University of Guelph .

IFC. 2011. Implementing Food Safety Management Systems in Ukrainian Food Processing Enterprises, Kyiv: International Finance Corporation.

Khalid SMN. 2012. Barries in HACCP implementation in Afghanistan. [Online] Available at: http://fqmsc.blogspot. com/2012/10/barries-in-haccp-implementation-in.html [Accessed 19 March 2015].

Khalid SMN. 2012b. Implementation of HACCP in the catering Industry (Master thesis). Lille: ISA-Lille Catholic University.

Khalid SMN. 2014. Importance of establishing a food authority (translated from Dari). [Online] Available at: http://8am.af/needed-beget-office-single-for-controlfood/[Accessed 6 Feb 2015].

Khalid SMN. 2015. Food Labeling Regulations in South Asian Association for Regional Cooperation (SAARC) Countries: Benefits, Challenges and Implications. Turkish Journal of Agriculture - Food Science and Technology, 3: 196-203.

Khelwatgar N. 2009. Voice of the city: City bakeries (original in Dari). [Online] Available at: http://www.bbc.co.uk /nazer/lifeandlearning_dari/story/2009/10/printable/091007_wsaep-cv-wk41.shtml [Accessed 19 March 2015].

Klaeijsen B. 2013. Food safety threats call for proactive approach by all stakeholders. [Online] Available at: http://www.scmp. com/comment/insight-opinion/article/1342078/food-safetythreats-call-proactive-approach-all-stakeholders [Accessed 31 Jan 2015].

Lu J, Pua XH, Liu CT, Chang CL, Cheng KC. 2014. The implementation of HACCP management system in a chocolate ice cream plant. Journal of Food and Drug Analysis 22: 391398.

Maldonado ES, Henson SJ, Caswell JA, Leos LA, Martinez PA, Aranda G, Cadena JA. 2005. Cost-benefit analysis of HACCP implementation in the Mexican meat industry. Food Control 16: 375-381.

Maldonado-Simán E, Martínez-Hernández PA, García-Muñiz JG, Cadena-Meneses J. 2014. Comparison of implementing HACCP systems of exporter Mexican and Chinese meat enterprises. Food Control 38: 109-115.

Massimo C, Kinyanjui W, Njue S, Joseph G, Nyorangi O, William O. 2013. Opportunities and Challenges of Setting-Up an Articulate HACCP System in Export Slaughterhouses in Countries Emerging from Conflict: An Appraisal of NorthWestern Somalia. Food and Nutrition Sciences 4: 126-130.

Miljkovic D, Nganje W, Onyango B. 2009. Offsetting behaviour and the benefits of food safety regulation. Journal of Food Safety 29: 49-58.

MoPH. 2009. Afghanistan Public Health Law. Kabul: Ministry of Justice: Official Gazzette.

MoPH. 2011. One day workshop held for medicine and food quality control in MoPH (translated from Dari). [Online] Available at: http://moph.gov.af/fa/news/5052[Accessed 6 Feb 2015].

Mortimore S. 2001. Problems Encountered Applying the HACCP Approach to Food Safety: (If HACCP Can Work So Well, Then Why Do So Many Businesses Have Problems with It?). Australian Journal of Hospitality Management 7: (No. 2).

Motarjemi Y, Wallace C, Mortimore S. 2014. Chapter 32 - HACCP Misconceptions. In: Food Safety Management. s.1.:s.n., 873887.

Mundi Index. 2014. Afghanistan GDP - per capita (PPP). [Online] Available at: http://www.indexmundi.com/afghanistan/ gdp_per_capita_(ppp).html[Accessed 6 Feb 2015]. 
NMFB. 2014. Annual Report 2013, Kabul, Afghanistan: National Medicine and Food Board and Food Committee of Ministry of Public Health.

Quraishi AH. 2012. Assessing the Regulatory Framework for Medicines and Food in Afghanistan. Amesterdam, Centennial Congress of Pharmacy and Pharmaceutical Sciences: International Pharmaceutical Federation's .

Rahimi MA. 2014. Can Food Stabilise Afghanistan?. [Online] Available at: http://mail.gov.af/en/page/5188[Accessed 31 Jan 2015].

Rostron KI. 2012. Strategies, Challenges and Outcomes in the Development and Implementation of Food Control Systems: An International Perspective from Policy Makers. s.l.: University of Salford.

Sabir S. 2014. Three person arrested for selling dog meat in Herat. [Online] Available at: http://da.azadiradio.org/content/article /26718557.html[Accessed 19 March 2015].

Shah SM. 2009. Main Investment Opportunities in Afghanistan, Kabul, Afghanistan: Afghanistan Investment Support Agency.

Sözen BU, Hecer C. 2013. Is HACCP a Difficult Food Safety System to Implement?. Journal of Biological and Environmental Sciences, 7: 33-38.

Stanley R, Knight C, Bodnar F. 2011. Experiences and challenges in the development of an organic HACCP system. NJASWageningen Journal of Life Sciences 58: 117-121.
Stier RF, Posnick LM, Kim H. 2003. Constraints to HACCP Implementation in Developing Countries, Part III. Food Safety Magazine.

Taylor E. 2001. HACCP in small companies: benefit or burden?. Food Control 12: 217-222.

Trafialek J, Kolanowski W. 2014. Application of failure Mode and effect analysis (FMEA) for audit of HACCP system. Food Control 44: 35-44.

Wallace C. 2014. Food Safety Assurance System: Hazard Analysis and Critical Control Point System (HACCP): Principles and Practices 4: 226-239.

WHO. 2014. Food safety: Fact sheet N 399. [Online] Available at: http://www.who.int/mediacentre/factsheets/fs399/en/[Accessed 31 Jan 2015].

Wong DLF. 2007. Defining the Responsibilities of Stakeholders within a National Strategy for Food Safety and Control. Hong Kong, s.n.

World Bank. 2015. Afghanistan:Data. [Online] Available at: http://data.worldbank.org/country/afghanistan [Accessed 6 Feb 2015].

Wu S-L. 2013. Innovative Food Safety Strategies in a Pioneering Hotel. Food and Nutrition Sciences 4: 1054-1059.

Zafar M. 2005. First Draft Country Report on the Status and Perspectives of the Animal Genetic Resources Development and Conservation in Islamic Republic of Afghanistan, Kabul, Afghanistan: FAO. 